\title{
THE COVID-19 PANDEMIC AND THE IMPLEMENTATION OF THE EUROPEAN GREEN DEAL
}

\author{
Melita Carević, PhD, Assistant Professor \\ Faculty of Law, University of Zagreb \\ Trg Republike Hrvatske 14, 10000 Zagreb, Croatia \\ mcarevic@pravo.hr
}

\begin{abstract}
This paper aims to explore how the COVID-19 pandemic influenced the implementation of the European Green Deal and to which extent have the European Union's green growth and sustainable development goals been incorporated into its COVID-19 Recovery Strategy. The European Union's Green Deal, a 'generation defining' growth strategy, which lays down the strategic pathway of the European Union's economic development for the upcoming two decades, has been faced with a major challenge shortly after its adoption in December 2019. However, despite the COVID-19 pandemic, which has continuously been putting all European Union member states to a harsh challenge during the past year, climate change and the green transition have been at the top of the political agenda in the European Union and have managed to occupy the attention of the mainstream politics and European Union citizens. Furthermore, the unprecedented levels of public financing which have been mobilised due to the pandemic have provided an opportunity for speeding up the green transition, without which the achievement of the Green Deal's main aims and the fulfilment of the European Union's obligations under the Paris Agreement would likely be put in question. In order to analyse how the has the COVID-19 pandemic influenced the implementation of the Green Deal, the paper first examines how the member states and the European Union institutions initially reacted to the idea of pursuing the implementation of the Green Deal simultaneously with economic recovery. This is accomplished through an analysis of statements given by the European Union and member state officials and the adopted measures and legislative proposals. The paper then focuses on publicly available data on legislative delays in regard to the implementation of the Green Deal which took place due to the pandemic and concludes that no significant postponements occurred. It subsequently turns to examine which measures have been adopted at the European Union level that link the economic recovery and the green transition. In this regard, special attention is paid to the Recovery and Resilience Facility and its measures aimed at ensuring that member states pursue climate change and environmental objectives in their recovery plans. Given the size of the public investments which will take place in the following years, the paper emphasises the importance of stringent environmental standards in order to ensure that they contribute to the green transition and avoid a fossil fuel lock-in.
\end{abstract}

Keywords: European Green Deal, climate change, carbon neutrality, green transition, COVID-19 pandemic, Recovery and Resilience Mechanism. 


\section{INTRODUCTION}

The European Green Deal, ${ }^{1}$ which was presented in December 2019 by the newly appointed European Commission on its $11^{\text {th }}$ day in office, has revolutionised the EU political discourse and has put climate change and the green transition at the top of the political agenda. The choice of climate change as a strategic priority was a logical one for the European Commission. It builds upon the image of the EU as a green leader, which has gained reinforced momentum after the $16^{\text {th }}$ Conference of the Parties to the United Nations Framework Convention on Climate Change in Cancun in 2010 and especially after the adoption of the Paris Agreement on Climate Change in 2015. ${ }^{2}$ Such an image reinforces the EU's position and legitimacy both internally and externally. ${ }^{3}$ On the internal level, it came as the perfect and well-timed answer to the fast-growing consensus among EU citizens on the dangers of climate change ${ }^{4}$ and increased public attention being paid to the issue, prompted by the Fridays for Future school strikes which gathered 13 million participants across the globe. ${ }^{5}$ In this regard, the EU once again gained renewed legitimacy by engaging in environmental protection, an issues of common concern of its citizens. On the external level, the reinforcement of its image of a green leader contributes to its global influence and offers it a first-mover advantage in developing new technologies. These advantages were recognised by the European Council in 2019, when it announced "building a climate-neutral, green, fair and social Europe" as one of EU's priorities for the near future. ${ }^{6}$ The European Com-

1 European Commission, Communication from The Commission to the European Parliament, the European Council, the Council, the European Economic and Social Committee and the Committee of the Regions - The European Green Deal, COM(2019) 640 final; European Commission, A European Green Deal [https://ec.europa.eu/info/strategy/priorities-2019-2024/european-green-deal_en], Accessed 5 May 2021.

2 Wurzel, R. K. W.; Liefferink, D., Connelly, J., Introduction European Union climate leadership, in Wurzel, R. K. W.; Connelly, J.; Liefferink, D., (eds.), The European Union in International Change Politics - Still taking a lead?, Routledge, 2018, p 8-9.

3 Torney, D., European Climate Leadership in Question - Policies toward China and India, The MIT Press, 2015, p. 40-41.

4 Special Eurbarometer Report, 490 Climate Change, April 209, p. 9-10., [https://ec.europa.eu/clima/ sites/clima/files/support/docs/report_2019_en.pdf], Accessed 5 May 2021.

The growing support of EU citizens for environmental protection has also been reflected in 2019 elections for the European Parliament, in which the Greens have obtained $9.85 \%$ of MEPs, in comparison to the previously held $6.94 \%$. Calculated on the basis of data available at European Parliament, 2019 European election results, [https:/www.europarl.europa.eu/election-results-2019/en/tools/comparative-tool/], Accessed 5 May 2021.

5 Fridays For Future, [https://fridaysforfuture.org/], Accessed 5 May 2021.

6 European Council, A new strategic Agenda 2019-2024, p. 5., https://www.consilium.europa.eu/media/39914/a-new-strategic-agenda-2019-2024.pdf], Accessed 5 May 2021. The urgency to act and the importance of aligning EU action with the objective of keeping the rise in global temperature under $1.5^{\circ} \mathrm{C}$ was emphasised by the European Parliament in the European Parliament Resolution of 28 No- 
mission's Green Deal builds upon that momentum with a fresh political agenda at its focus, which has a strong unifying potential for the EU as a whole, which was very much needed after the sharply dividing issues which have recently been casting a shadow on the European project, such as the economic crisis, migration, Brexit and the rule of law, to name a few.

At its very outset, the European Green Deal proclaims tackling climate change as a "generation's defining task" and aims to "transform the EU into a fair and prosperous society, with a modern, resource-efficient and competitive economy where there are no net emissions of greenhouse gases in 2050 and where economic growth is decoupled from resource use." In order to achieve this, the Green Deal identifies regulatory tasks that are to take place across all sectors of the economy. Special emphasis is being put on creating a circular economy and sustainable use of resources, decarbonising the energy sector, increasing energy efficiency of buildings, accelerating the transition to sustainable and smart transportation, the "Farm to Fork" strategy for ensuring a sustainable, fair and healthy food system, preserving and restoring ecosystems and biodiversity, as well as eliminating pollution. The financial sector, investments into research and development, as well as education are to play a crucial role at this. In order to ensure that no one is left behind in this transition, the Green Deal envisages a Just Transition Mechanism and a Just Transition Fund. ${ }^{8}$ The transition towards green economy and the achievement of the $40 \%$ reduction target of greenhouse gas emissions by 2030 was estimated to require " $€ 260$ billion of additional annual investment", which represents "about 1.5\% od 2018 GDP". ' From December 2019, the 2030 emissions reduction target has risen to $55 \%$, and so have the estimated expenses for reaching it.

Some of the biggest challenges that the implementation of the Green Deal is facing are the risk of a fossil fuel lock-in and downsizing the Union's global environmental footprint. ${ }^{10}$ The Green Deal, which is for the most part centred around

vember 2019 on the climate and environment emergency (2019/2930(RSP)) [https://www.europarl. europa.eu/doceo/document/TA-9-2019-0078_EN.html], Accessed 5 May 2021.

7 European Commission, Communication from The Commission to the European Parliament, the European Council, the Council, the European Economic and Social Committee and the Committee of the Regions - The European Green Deal, COM(2019) 640 final, page 2.

8 Proposal for a Regulation of the European Parliament and of the Council establishing the Transition Fund, Just COM/2020/22 final.

9 European Commission, Communication from The Commission to the European Parliament, the European Council, the Council, the European Economic and Social Committee and the Committee of the Regions - The European Green Deal, COM(2019) 640 final, page 15.

10 For a description of the EU's environmental footprint, see Scott, J., Reducing the EU's Global Environmental Footprint, German Law Journal, Vol. 21, 2020, pp. 10-16. 
the concept of green growth, does not in itself advocate a radical shift of the preexisting environmental or climate change related policies. ${ }^{11}$ In its present form, and state of implementation it is therefore not well-equipped to deal with overconsumption issues. However, provided that its implementation measures do not lead to greenwashing, it has potential to successfully deal with its other major challenge, a fossil fuel lock-in. This paper will explore which role has the COVID-19 pandemic played in this respect.

During the past year, climate change and the green transition have been at the top of the political agenda in the EU and have managed to occupy the attention of the mainstream politics and EU citizens despite the COVID-19 pandemic. The pandemic recovery and the implementation of the Green Deal have been addressed as "two sides of the same coin". ${ }^{12}$ The two are indeed inseparable. Within the first quarter of 2020, the COVID-19 pandemic has put the newly adopted Green Deal to a harsh, to be, or not to be test. ${ }^{13}$ However, at the same time the unprecedented levels of public financing which have been mobilised due to the pandemic have provided an opportunity for speeding up the green transition, without which the achievement of the Green Deal's main aims and the fulfilment of the European Union's obligations under the Paris Agreement seem unlikely.

In order to explore how the COVID-19 pandemic influenced the implementation of the Green Deal, the paper will firstly shortly examine how the European Union institutions and its member states initially reacted to the pandemic and the idea of continuing the implementation of the European Green Deal. Secondly, the paper describes legislative delays in the implementation of the Green Deal which took place due to the pandemic. The subsequent, third part of the paper is dedicated to the financial instruments which the European Union adopted in response to the pandemic and the measures they contain which are aimed at promoting green recovery of the member states' economies. The paper's fourth part focuses on the fossil fuel lock-in, which might be the result of massive public spending with no

11 Ossewaarde, M.; Ossewaarde-Lowtoo, R., The EU's Green Deal: A Third Alternative to Green Growth and Degrowth?, Sustainability, Vol. 12, No. 23, 2021, 9825; [https://doi.org/10.3390/su12239825], p. 12.

12 Potočnik, J., The European Green Deal and a post Covid-19 prosperity, [https://medium.com/circulatenews/the-european-green-deal-and-a-post-covid-19-prosperity-e95608f7606f], Accessed 5 May 2021.

13 Colli, F., The end of 'business as usual'? COVID-19 and the European Green Deal, Egmont - European Policy Briefs, No 60, May 2020, [https://www.egmontinstitute.be/content/uploads/2020/05/EPB60. pdf?type=pdf], Accessed 5 May 2021; Elkerbout, M., et al., The European Green Deal after Corona: Implications for EU climate policy, CEPS Policy Insights, No 2020-06 / March 2020, [https://www. ceps.eu/ceps-publications/the-european-green-deal-after-corona/], Accessed 5 May 2021. 
green strings attached. The final part of the paper summarises the findings of the paper.

\section{INITIAL REACTIONS TO THE PANDEMIC BY THE EU INSTITUTIONS AND MEMBER STATES}

At the beginning of spring 2020, when the harsh consequences of the COVID-19 pandemic were becoming visible all across the European Union, some member states expressed concerns about the capacity of their economies to handle two crises at the same time. Members of the Czech Government called for an abandonment of the Green Deal and for the weakening of carbon dioxide emission standards for cars, while Poland advocated disconnecting from the ETS. ${ }^{14}$ In addition, several MEPs have called upon the EU to "re-examine its political priorities" and to "postpone new legislation under initiatives such as the European Green Deal." ${ }^{15}$ However, the European Commission quickly took a decisive stance to continue with the implementation in the Green Deal and emphasised the need for a green post-pandemic recovery. ${ }^{16}$ At the end of March the European Council affirmed that the green transition is to be integrated into the Union's response to the pandemic and its recovery plan. ${ }^{17}$ In addition, environmental ministers from

14 Oroschakoff, K., Coronavirus crisis cash threatens EU green plans, Politico, March 19, 2020, [https:// www.politico.eu/article/coronavirus-crisis-cash-threatens-eu-green-plans/?utm_source=POLITICO. EU\&utm_campaign=0199d91bba-EMAIL_CAMPAIGN_2020_05_22_01_28\&utm_medium=email\&utm_term=0_10959edeb5-0199d91bba-189693589], Accessed 5 May 2021; Euractiv, Czech PM urges EU to ditch Green Deal amid virus, 17 March 2020, [https://www.euractiv.com/section/energy-environment/news/czech-pm-urges-eu-to-ditch-green-deal-amid-virus/], Accessed 5 May 2021; Euractiv, Poland says virus fallout makes it 'even more difficult' to hit EU climate goal, 27 March 2020, [https://www.euractiv.com/section/energy-environment/news/poland-says-virus-fallout-makes-iteven-more-difficult-to-hit-eu-climate-goal/], Accessed 5 May 2021.

15 Politico, [https://www.politico.eu/wp-content/uploads/2020/03/vdL-Sassoli-Michel-letter-26.03.2020signatures-as-of-29.03.2020.pdf?utm_source=POLITICO.EU\&utm_campaign=4eb3480635-EMAIL_ CAMPAIGN_2020_03_30_04_568utm_medium $=$ email $\& u t m \_t e r m=0 \_10959$ edeb5 -4 eb3480635-189693589], Accessed 5 May 2021.

16 Dupont, C.; Oberthür, S.; von Homeyer, I., The Covid-19 crisis: a critical juncture for EU climate policy development?, Journal of European Integration, Vol. 42, No. 8, 2020, 1095-1110, DOI: 10.1080/07036337.2020.1853117, pp. 1104-1105; Piccard, B., Timmermans, F., Which world do we want after COVID-19?, Euractiv, 16 April 2020, [https://www.euractiv.com/section/energy-environment/opinion/which-world-do-we-want-after-covid-19/], Accessed 5 May 2021; Čavoški, A., An ambitious and climate-focused Commission agenda for post COVID-19 EU, Environmental Politics, Vol. 29, No. 6, 2020, pp. 1112-1117, DOI: 10.1080/09644016.2020.1784010, p. 1116.

17 Joint statement of the Members of the European Council, 26 March 2020, [https://www.consilium. europa.eu//media/43076/26-vc-euco-statement-en.pdf?utm_source=POLITICO.EU\&utm_campaign=11f700a891-EMAIL_CAMPAIGN_2020_03_26_10_128utm_medium=email\&utm_term= 0_10959edeb5-11f700a891-189693589], Accessed 5 May 2021; Simon, F., EU leaders back green transition' in pandemic recovery plan, Euractiv, 27 March 2020, [https://www.euractiv.com/section/ 
17 member states expressed their support of the continued implementation of the Green Deal and scaling up investments "notably in the fields of sustainable mobility, renewable energy, building renovations, research and innovation, the recovery of biodiversity and the circular economy." ${ }^{18}$ In its resolution from 17 April 2020, the European Parliament stated that the Green Deal should be at the core of the recovery package and highlighted the need to align the EU's response to the pandemic with its objective of climate neutrality. ${ }^{19}$ The European Commission President also emphasised the need for strengthening the investments under the Green Deal and pointed out the first-mover advantage that the green recovery would bring to the Union economy. ${ }^{20}$ The importance of approaching climate change and the pandemic with equal seriousness was furthermore painted by the UN secretary-general António Guterres at the very outset of the pandemic. ${ }^{21}$

\section{THE PANDEMIC AND THE GREEN DEAL LEGISLATIVE SCHEDULE}

The implementation of the Green Deal had been facing a very tight timeline even before the pandemic. ${ }^{22}$ The EU was planning to revise its greenhouse gas emission target by summer $2020,{ }^{23}$ in order to prepare for the $26^{\text {th }}$ Conference of the Parties to the United Nations Framework Convention on Climate Change (hereinafter: the COP 26), which was scheduled for November 2020. Working fast under these time constraints, the European Commission presented is Proposal for a European

energy-environment/news/eu-leaders-back-green-transition-in-pandemic-recovery-plan/], Accessed 5 May 2021.

18 Climate Home News, European Green Deal must be central to a resilient recovery after Covid-19, 9 April 2020, [https://www.climatechangenews.com/2020/04/09/european-green-deal-must-central-resilient-recovery-covid-19/], Accessed 5 May 2021.

19 European Parliament Resolution of 17 April 2020 on EU coordinated action to combat the COVID-19 pandemic and its consequences (2020/2616(RSP), point 20., [https://www.europarl.europa.eu/ doceo/document/TA-9-2020-0054_EN.html], Accessed 5 May 2021.

20 European Commission, Speech by President von der Leyen at the European Parliament Plenary on the EU coordinated action to combat the coronavirus pandemic and its consequences, 16 April 2020, [https://ec.europa.eu/commission/presscorner/detail/en/SPEECH_20_675], Accessed 5 May 2021.

${ }_{21}$ Gornall, J., Climate change will still be a threat after COVID-19 is gone, Euractiv, 17 March 2020, [https://www.euractiv.com/section/climate-environment/opinion/climate-change-will-still-be-athreat-after-covid-19-is-gone/], Accessed 5 May 2021.

22 Simon, F., 2020: A test year for Europe's much-vaunted Green Deal, 2 January 2020, [https://www.euractiv.com/section/energy-environment/news/2020-a-test-year-for-europes-much-vaunted-green-deal/], Accessed 5 May 2021.

23 European Commission, Communication from The Commission to the European Parliament, the European Council, the Council, the European Economic and Social Committee and the Committee of the Regions - The European Green Deal, COM(2019) 640 final, Annex to the Communication on the European Green Deal: Roadmap - Key Actions, page 2. 
Climate Law on 4 March 2020, which left the most sensitive issue of the 2030 greenhouse gas emission reduction target to be decided in September 2020. ${ }^{24}$ Despite the pandemic, within the first half of March 2020 the European Commission adopted the European Industrial Strategy ${ }^{25}$ and a New Circular Economy Action Plan, ${ }^{26}$ and opened the European Public Pact for public consultations. ${ }^{27}$ However, some instruments, such as the EU Biodiversity Strategy for $2030^{28}$ and the Farm to Fork Strategy ${ }^{29}$ which were originally scheduled for adoption in March 2020 according to the timeline presented in the Green Deal Proposal, were postponed and instead adopted on 20 May 2020. The biggest delays took place in relation to several areas considered non-essential, such as New EU Strategy on Adaptation to Climate Change and the New EU Forest Strategy, which were originally scheduled for the last quarter of 2020, but were postponed for $2021 .{ }^{30}$

Due to the pandemic, at the beginning of April 2020 it was decided the COP 26 was to be postponed and it was later scheduled for November 2021, ${ }^{31}$ which gave the EU precious additional time for setting its 2030 greenhouse gas emission reduction target. The European Commission presented its proposal for a 55\% reduction target by 2030, with 1990 as the baseline year for counting the reductions, on 17 September 2020. ${ }^{32}$ After very long and divisive negotiations, the

24 European Commission, Proposal for a Regulation of the European Parliament and of the Council establishing the framework for achieving climate neutrality and amending Regulation (EU) 2018/1999 (European Climate Law), COM/2020/80 final, Article 2(3).

25 Communication from the Commission to the European Parliament, the Council, the European Economic and Social Committee and the Committee of the Regions - A New Industrial Strategy for Europe, COM/2020/102 final.

26 Communication from the Commission to the European Parliament, the Council, the European Economic and Social Committee and the Committee of the Regions - A New Circular Economy Action Plan for a Cleaner and More Competitive Europe, COM/2020/98 final.

27 For an overview of the acts adopted under the Green Deal framework, see European Commission, $A$ European Green Deal, [https://ec.europa.eu/info/strategy/priorities-2019-2024/european-green-deal_ en\#documents], Accessed 5 May 2021.

28 Communication from the Commission to the European Parliament, the Council, the European Economic and Social Committee and the Committee of the Regions - EU Biodiversity Strategy for 2030 Bringing nature back into our lives, COM/2020/380 final.

29 Communication from the Commission to the European Parliament, the Council, the European Economic and Social Committee and the Committee of the Regions -A Farm to Fork Strategy for a fair, healthy and environmentally-friendly food system, COM/2020/381 final.

30 Simon, F., Leaked: Full list of delayed European Green Deal initiatives, Euractiv, 16 April 2020, [https://www.euractiv.com/section/energy-environment/news/leaked-full-list-of-delayed-european-green-deal-initiatives/], Accessed 5 May 2021.

31 UN, COP 26 postponed [https://unfccc.int/news/cop26-postponed], Accessed 5 May 2021.

32 Communication from the Commission to the European Parliament, the Council, the European Economic and Social Committee and the Committee of the Regions - Stepping up Europe's 2030 climate ambition - Investing in a climate-neutral future for the benefit of our people, COM(2020) 562 final. 
European Parliament and the Council agreed upon the 55\% reduction target on 21 April 2021 and upon the legal obligation to reach climate neutrality by 2050, just ahead of the Earth Day Climate Summit organised by the US President. ${ }^{33}$ The formal adoption of the agreed targets, along with other legislative changes, such as the amendment of the Emissions Trading Scheme, is scheduled for July 2021.

Despite causing some initial delays, the pandemic has thus not seriously shifted the legislative timeline for the implementation of the European Green Deal. Most importantly, the European Union managed to agree its mid-term and long-term greenhouse gas emission reduction targets in time for COP 26. Several factors have played an important role at this - the postponement of COP 26 for November 2021, the adoption of similar targets by other jurisdictions and the leverage which the financial stimulus included in the Recovery and Resilience Mechanism had on indecisive member states.

\section{EUROPEAN UNION'S FINANCING OF THE POST-PANDEMIC GREEN RECOVERY}

In order to facilitate the recovery of member states' economies, the European Union adopted a Next Generation EU, a temporary recovery instrument of 750 billion euro, 360 billion of which consists in loans, and 390 billion of which in grants. ${ }^{34}$ The Commission in empowered to borrow those funds on the capital markets on behalf of the EU. ${ }^{35}$ Together with the Multiannual Financial Framework, the Union's long-term budget for the period from 2021 until 2027, it provides an unprecedented stimulus package of 1824.3 billion euro aimed at rebuilding "a greener, more digital and more resilient Europe". ${ }^{36}$

The Next Generation EU recovery plan was proposed by the European Commission on 27 May 202037. The European Parliament and the Council first agreed

33 European Parliament, President Biden's climate summit [https://www.europarl.europa.eu/RegData/ etudes/ATAG/2021/690583/EPRS_ATA(2021)690583_EN.pdf], Accessed 5 May 2021; European Commission, European Climate Law, [https://ec.europa.eu/clima/policies/eu-climate-action/law_en], Accessed 5 May 2021.

34 Special meeting of the European Council (17, 18, 19, 20 and 21 July 2020) - Conclusions, EUCO 10/20, point A5 and A6, [https://www.consilium.europa.eu/media/45109/210720-euco-final-conclusions-en.pdf], Accessed 5 May 2021.

35 Ibid., A5.

36 European Commission, Recovery Plan for Europe, [https://ec.europa.eu/info/strategy/recovery-plan-europe_en], Accessed 5 May 2021.

37 Communication from the Commission to the European Parliament, the Council, the European Economic and Social Committee and the Committee of the Regions - Europe's moment: Repair and Prepare for the Next Generation, COM/2020/456 final. 
upon the recovery plan in the second half of July 2020, and finalised the agreement on 10 November 2020. ${ }^{38}$ The Multiannual Financial Framework and the recovery plan were adopted on 17 December $2020 .{ }^{39}$ According to the agreement reached in July 2021, 30\% of the overall spending of both the Multiannual Financial Framework and the Next Generation EU is to be dedicated to climate action, which is to be reflected in sectoral legislation, and "all EU expenditure should be consistent with Paris Agreement objectives" and "the 'do no harm' principle of the European Green Deal." ${ }^{40}$ In figures, under the Multiannual Financial Framework a total of 356374 billion euro is dedicated to the Natural resources and the environment category. ${ }^{41}$

The main instrument of the Next Generation EU recovery plan is the Recovery and Resilience Facility, worth 672.5 billion euro and agreed upon on 10 February $2021 .^{42}$ As one of its general objectives, the Recovery and Resilience Facility lists "contributing to the achievement of the Union's 2030 climate targets" and "complying with the objective of EU climate neutrality by 2050", as means of "contributing to the upward economic and social convergence, restoring and promoting sustainable growth and the integration of the economies of the Union, fostering high quality employment creation", among others. ${ }^{43}$ The financing through this mechanism is available for the period from 2021 until 2026 and it contains 312.5 billion euro in grants and 360 billion euro in loans. ${ }^{44}$

In order to obtain the funds from the Recovery and Resilience Facility, member states are to prepare national recovery and resilience plans which contain their investment agenda. ${ }^{45}$ The provisional deadline for the submission of national plans is set on 30 April. Among other elements, national plans have to contain:

38 Legislative Train Schedule, New Boost for Jobs, Growth and Investment [https://www.europarl.europa. eu/legislative-train/theme-new-boost-for-jobs-growth-and-investment/file-mff-2021-2027-mff], Accessed 5 May 2021.

39 European Council, Council of the European Union, Timeline - Council actions on COVID-19, [https:// www.consilium.europa.eu/en/policies/coronavirus/timeline/], Accessed 5 May 2021.

40 Special meeting of the European Council (17, 18, 19, 20 and 21 July 2020) - Conclusions, EUCO 10/20, point A21 and 18, [https://www.consilium.europa.eu/media/45109/210720-euco-final-conclusions-en.pdf], Accessed 5 May 2021.

41 Council Regulation (EU, Euratom) 2020/2093 of 17 December 2020 laying down the multiannual financial framework for the years 2021 to 2027, [2020] OJ L 433I/11, Annex I.

42 Taylor, K., Historic step' as European Parliament approves green recovery fund, Euractiv, 10 February 2021, [https://www.euractiv.com/section/energy-environment/news/historic-step-as-european-parliament-approves-green-recovery-fund/], Accessed 5 May 2021.

43 Regulation (EU) 2021/241 of the European Parliament and of the Council of 12 February 2021 establishing the Recovery and Resilience Facility, [2021] OJ L57/17, Article 4.

44 Ibid.., Article 6.

45 Ibid.., Articles 17, 18. 
"a qualitative explanation of how the measures in the recovery and resilience plan are expected to contribute to the green transition, including biodiversity, or to addressing the challenges resulting therefrom, and whether they account for an amount that represents at least $37 \%$ of the recovery and resilience plan's total allocation, based on the methodology for climate tracking set out in Annex VI [...]," ${ }^{6}$

and explain:

"how the recovery and resilience plan ensures that no measure for the implementation of reforms and investments included in the recovery and resilience plan does significant harm to environmental objectives within the meaning of Article 17 of Regulation (EU) 2020/852 (the principle of 'do no significant harm')."47

Furthermore, it is explicitly proscribed that financing through the Recovery and Resilience Facility is only available to measures which comply with the principle of doing 'no significant harm' to environmental objectives, within the meaning of Regulation (EU) 2020/852 on the establishment of a framework to facilitate sustainable investment, and amending Regulation (EU) 2019/2088. ${ }^{48}$

Within two months of the submission of the national plans, the European Commission assesses them and when necessary, may ask for additional information and member states may revise their plans in case of need. ${ }^{49}$ Pursuant to Article 19(3) of the Recovery and Resilience Facility Regulation, one of the assessment criteria, besides effectiveness, efficiency and coherence is the relevance of the plans. ${ }^{50}$ Within the latter criteria the European Commission verifies whether the national plan "contains measures that effectively contribute to the green transition, including biodiversity, or to addressing the challenges resulting therefrom, and whether they account for an amount which represents at least $37 \%$ of the recovery and resilience plan's total allocation, based on the methodology for climate tracking set out in Annex VI," ${ }^{11}$ and whether it complies with the 'do no significant harm' principle. ${ }^{52}$ Failure to comply with the criteria prescribed under the abovementioned Article 19(3) prevents the member state concerned to benefit from financial contribution under the Recovery and Resilience Facility. ${ }^{53}$ If all the criteria are

\footnotetext{
$46 \quad$ Ibid.., Article 19(e).

47 Ibid.., Article 19(3)d.

48 Ibid.., Article 5.

49 Ibid., Article 19(1).

50 Ibid.., Article 19(3).

$51 \quad$ Ibid.., Article 19(3)e.

$52 \quad$ Ibid.., Article 19(3)d.

53 Ibid.., Article 20(4)c.
} 
met, the assessment of the recovery plans is approved by the Council, upon the proposal of the European Commission. ${ }^{54}$

At the time of writing this paper, the following 17 member states have submitted their recovery plans: Belgium, Denmark, Germany, Greece, Spain, France, Croatia, Italy, Latvia, Lithuania, Luxembourg, Hungary, Austria, Poland, Portugal, Slovenia, and Slovakia. ${ }^{55}$ According to the first assessment of the national recovery plans performed within the Green Recovery Tracker project, the recovery plans of Denmark, Bulgaria and Slovakia can make a positive impact on the green transition, the ones from Estonia, Portugal, Poland, Romania and Spain have potential for a positive impact, but lack information which would affirm such a conclusion, while the recovery plans of France, Germany and Latvia are estimated to have a moderate impact on the green transition. ${ }^{56}$ The Czech recovery plan is expected to have an overall positive impact, but contains elements which present a risk of a fossil fuel lock-in. ${ }^{57}$ The highest positive impact on the green transition is expected from the Finish recovery plan, which dedicates $42 \%$ of the EU spending on green projects. ${ }^{58}$ The lowest percentage of such spending, only $5 \%$, is envisaged by the Slovenian recovery plan, which is even estimated to negatively impact the green transition. ${ }^{59}$ Other national recovery plans which have been submitted are still under preliminary evaluation.

In case their recovery plans are approved, member states may ask to receive prefinancing payment of up to $13 \%$ of their funding. ${ }^{60}$ The majority of the funding under the Recovery and Resilience Facility, $70 \%$, is to be made available by the

54 Ibid.., Article 20(1). Examples of investments linked to the green transition, which are presumed to be met with approval from the European Commission, are given in European Commission's Guidance to Member States - Recovery and Resilience Plans, SWD(2021) 12 final, pp. 25-26.

55 European Commission, Recovery and Resilience Facility: Croatia and Lithuania submit official recovery and resilience plans, [https://ec.europa.eu/commission/presscorner/detail/en/IP_21_2501], Accessed 15 May 2021.

56 Green Recovery Tracker, Country reports, [https://www.greenrecoverytracker.org/country-reports-overview], Accessed 15 May 2021. For a different preliminary analysis of national recovery plans, see Darvas, Z.; Tagliapietra, S., Setting Europe's economic recovery in motion: a first look at national plans, Bruegel Blog, 29 April 2021, [https://www.bruegel.org/2021/04/setting-europes-economic-recoveryin-motion-a-first-look-at-national-plans/], Accessed 15 May 2021.

57 Ibid.

58 Ibid..

59 Ibid..

60 Regulation (EU) 2021/241 of the European Parliament and of the Council of 12 February 2021 establishing the Recovery and Resilience Facility, [2021] OJ L57/17, Article 13. 
European Commission by the end of 2022, and the remaining 30\% by the end of 2023. ${ }^{61}$ All payments to the member states are to be made by the end of $2026 .{ }^{62}$

Financing of fossil fuel projects through the Recovery and Resilience Facility is not explicitly excluded, but as stated earlier, Article 5(2) of the Recovery and Resilience Facility Regulation requires that all measures which are financed through the mechanism respect the principle of 'do no significant harm'. The Technical guidance on the application of 'do no significant harm' under the Recovery and Resilience Facility Regulation state that, given the availability of low carbon alternatives, "measures related to power and/or heat generation using fossil fuels, as well as related transmission and distribution infrastructure, as a general rule should not be deemed compliant" with this principle. ${ }^{63}$ However, exceptions from this rule are envisaged on a case by case basis, for "measures related to power and/ or heat generation using natural gas, as well as related transmission and distribution infrastructure." ${ }^{64}$ This exception is available to member states which face significant challenges in transitioning from "more carbon-intensive energy sources, such as coal, lignite or oil", if the use of natural gas can lead to "particularly large and rapid reduction in GHG emissions," and if they comply with conditions for avoiding a "carbon-intensive lock-in effect" and other environmental conditions from the Technical guidelines. ${ }^{65}$ Some member states, such as Poland, Bulgaria, and the Czech Republic, have expressed strong criticism of the 'do no significant harm' principle and its criteria for the use of natural gas as a transition fuel, while others, such as Denmark, have voiced their concerns on lowering the limits imposed on the use of fossil fuels. ${ }^{66}$

In order to distinguish between environmentally friendly and unfriendly investments, the European Union has adopted the sustainable finance taxonomy. ${ }^{67}$ The first draft of European Commission's EU Taxonomy Climate Delegated Act did

$\overline{61} \quad$ Ibid.., Article 12.

62 Ibid.., Article 24.

63 European Commission Notice on Technical guidance on the application of 'do no significant harm' under the Recovery and Resilience Facility Regulation 2021/C 58/01, C/2021/1054, [2021] OJ C58/1., point 2.4.

64 Ibid..

65 Ibid..

66 Taylor, K., Czechs lead the charge against EU's 'do no harm' green criteria, 26 March 2021, Euractiv, [https://www.euractiv.com/section/climate-environment/news/czechs-lead-the-charge-against-eus-dono-harm-green-criteria/], Accessed 5 May 2021.

67 Regulation (EU) 2020/852 of the European Parliament and of the Council of 18 June 2020 on the establishment of a framework to facilitate sustainable investment, and amending Regulation (EU) 2019/2088, PE/20/2020/INIT [2020] OJ L 198/13. 
not recognise natural gas as a sustainable fuel, ${ }^{68}$ but it has subsequently been considered for inclusion given the strong pressure from Bulgaria, Croatia, Cyprus, the Czech Republic, Greece, Hungary, Malta, Poland, Romania, and Slovakia. ${ }^{69}$ The final decision about the classification of natural gas as sustainable/unsustainable has currently been postponed until the adoption of a complementary delegated act, which is expected by the end of $2021 .^{70}$

Concerns about the green transition of member states which are heavily reliant on fossil fuels have been to a certain extent addressed by the Just Transition Mechanism, envisaged by the Green Deal. Under the Next Generation EU recovery plan, financing of additional 10 billion euro has been envisaged for the Just Transition Fund, which forms part of the Mechanism, leaving at its disposal a total of 17,5 billion euro. ${ }^{71}$ These resources are aimed at alleviating the green transition for regions and sectors which are heavily dependent on fossil fuels, and can be used, inter alia, for re-skilling programmes, job creation and energy-efficient housing. ${ }^{72}$ The biggest recipients of the abovementioned funding are the coal-mining regions in Poland, Germany and Romania. ${ }^{73}$

The 'do no significant harm' principle, the mandatory $37 \%$ of envisaged green financing in member states' recovery plans, the sustainable finance taxonomy and the Just Transition Mechanism all have a common goal of preventing a fossil fuel lock-in of member states' economies. Given the unprecedented levels of public

68 Simon, F., Gas denied 'transition' fuel status in draft EU green finance rules, 11 November 2020, Euractiv, [https://www.euractiv.com/section/energy-environment/news/gas-denied-transition-fuel-status-in-eugreen-finance-rules/], Accessed 5 May 2021.

69 Simon, F., Brussels postponed green finance rules after 10 EU states wielded veto, 29 January 2021, Euractiv, [https://www.euractiv.com/section/energy-environment/news/brussels-postponed-green-financerules-after-10-eu-states-wielded-veto/], Accessed 5 May 2021.

70 European Commission, Questions and Answers: Taxonomy Climate Delegated Act and Amendments to Delegated Acts on fiduciary duties, investment and insurance advice, [https://ec.europa.eu/commission/ presscorner/detail/en/qanda_21_1805], Accessed 5 May 2021.

71 Special meeting of the European Council (17, 18, 19, 20 and 21 July 2020) - Conclusions, EUCO 10/20, point A14, [https://www.consilium.europa.eu/media/45109/210720-euco-final-conclusions-en.pdf], Accessed 5 May 2021; European Commission, The Just Transition Mechanism: making sure no one is left behind, [https://ec.europa.eu/info/strategy/priorities-2019-2024/european-green-deal/ actions-being-taken-eu/just-transition-mechanism_en], Accessed 5 May 2021.

72 European Commission, Communication from The Commission to the European Parliament, the European Council, the Council, the European Economic and Social Committee and the Committee of the Regions - The European Green Deal, COM(2019) 640 final, page 16.

73 Abnett, K., EU countries approve the green transition fund, look to challenges ahead, Reuters, 3 March 2021, [https://www.reuters.com/article/us-climate-change-eu-justtransition-idUSKCN2AV2D0], Accessed 5 May 2021; Kucharczyk, M., West Poland subregion aims to be first in the country to hit net zero, 21 January 2021, Euractiv, [https://www.euractiv.com/section/energy/news/west-poland-subregionaims-to-be-first-in-the-country-to-hit-net-zero/], Accessed 5 May 2021. 
financing which have been mobilised due to the pandemic, the investments which will occur in the following years will either speed up the green transition, or make it more expensive.

\section{AVOIDING A FOSSIL FUEL LOCK-IN}

In its recently published report, the International Energy Agency has performed an analysis of the reforms which need to take place in the energy sector in order for it to have net zero emissions by $2050 .^{74}$ The report states that the energy sector's "path to net zero emissions is narrow: staying on it requires immediate and massive deployment of all available clean and efficient energy technologies" and that no new oil or gas fields nor coal mine capacities are required to satisfy the energy demand. ${ }^{75}$ Given the authority of the International Energy Agency and the comprehensiveness and urgency of its report, it can be concluded that the risk of a fossil fuel lock-in is strongly present.

The importance of an energy transition, of removing subsidies for fossil fuels and avoiding a lock-in into unsustainable practices has also been recognised in the Green Deal. ${ }^{76}$ However, even though the wording of the Green Deal leaves no doubt about the importance of this aim and the scope of changes which are necessary for its realisation, its achievement in practice remains dubious. An analysis of the European Union's 2030 Climate and Energy Policy Framework preformed in the first half of 2020 revealed that the proposed legislative and policy changes were insufficient for enabling a transformation required by the European Union's commitments under the Paris Agreement. ${ }^{77}$ This shows that the prospective for a successful and timely implementation of the Green Deal was questionable at the outset. However, paradoxically, the COVID-19 pandemic, despite of its destructive consequences on member states' economies and tragic human losses, has made changes in many sectors inevitable, which in itself brings the implementation of

74 International Energy Agency, Net Zero by 2050 - A Roadmap for the Global Energy Sector, [https://iea. blob.core.windows.net/assets/4482cac7-edd6-4c03-b6a2-8e79792d16d9/NetZeroby2050-ARoadmapfortheGlobalEnergySector.pdf], Accessed 18 May 2021.

75 Ibid.., p.14 and 21.

76 European Commission, Communication from The Commission to the European Parliament, the European Council, the Council, the European Economic and Social Committee and the Committee of the Regions - The European Green Deal, COM(2019) 640 final, pages 2, 17; European Commission, Communication from The Commission to the European Parliament, the European Council, the Council, the European Economic and Social Committee and the Committee of the Regions - Powering a climate-neutral economy: An EU Strategy for Energy System Integration, COM/2020/299 final.

77 Kulovesi K.; Oberthür, S., Assessing the EU's 2030 Climate and Energy Policy Framework: Incremental change toward radical transformation? Review of European, Comparative and International Environmental Law (RECIEL) Vol. 29, No. 2, pp.151-166. DOI: 10.1111/reel.12358, at 165. 
the Green Deal not beyond the realms of possibility. The COVID-19 pandemic has demonstrated that decisive and large-scale state action is possible in case of an imminent threat and when public support is present. ${ }^{78}$

As explained above, the opportunity that large scale public investments employed for post-pandemic economic recovery presents for the green transition has been recognised by the European Union, and it has undertaken several steps to link the use of the financial resources with the green recovery. Some member states have engaged in additional action to ensure that the resources they were making available to undertakings in need do not reinforce polluting and carbon-intensive practices. For example, as a part of its stimulus package, alongside VAT reductions Germany doubled the purchase premium for electric vehicles, incentivising thus at the same time the recovery of the market and the greening of its road transport. ${ }^{79}$ Unfortunately, this noteworthy example of linking the economic recovery and the green transition is a rare one, but it depicts which level of opportunity member states currently have at their disposal for incentivising the markets to switch to green technologies, since similar types of market-intervention would be harder in normal market conditions. Some developments along similar lines took place in relation to bailouts for the airline industry. ${ }^{80}$ Austrian Airlines has, in return for a 450 million euro bailout undertaken several climate change related commitments, such as reducing its greenhouse gas emissions by $30 \%$ by 2030 and dropping short-haul flights for which railroad alternatives with a commute time of under 3 hours exist. ${ }^{81}$ Austria has also announced a raise in taxes which would influence the minimum price of air tickets. ${ }^{82}$ Much milder climate change related non-legally binding promises were also given by Air France, which re-

78 Hepburn, C., et al, Will COVID-19 fiscal recovery packages accelerate or retard progress on climate change?, Smith School Working Paper 20-02, p. 4, [https://www.smithschool.ox.ac.uk/publications/wpapers/ workingpaper20-02.pdf], Accessed 5 May 2021; Gemenne, F.; Depoux, A., What our response to the COVID-19 pandemic tells us of our capacity to respond to climate change, Environmental Research Letters, Vol 15, 2020, 101002, p. 1, https://doi.org/10.1088/1748-9326/abb851.

79 Posaner, J., German coalition agrees $€ 130 B$ economic rescue package, 4 June 2020, Politico, [https:// www.politico.eu/article/german-coalition-agrees-e130b-economic-rescue-package/], Accessed 5 May 2021

80 Transport \& Environment, Bailout Tracker, [https://www.transportenvironment.org/what-we-do/flying-and-climate-change/bailout-tracker], Accessed 5 May 2021; Greenpeace, European Airline Bailout Tracker, [https://www.greenpeace.org/eu-unit/issues/climate-energy/2725/airline-bailout-tracker/], Accessed 5 May 2021.

81 Transport \& Environment, Austrian Airlines' bailout 'climate conditions' explained, [https://www.transportenvironment.org/publications/austrian-airlines-bailout-climate-conditions-explained], Accessed 5 May 2021.

82 Ibid. This measure gas been suspected as protectionist by low cost airline operators. CAPA, Austrian Airlines bailout protected by taxes and fare floor, [https://centreforaviation.com/analysis/reports/austrian-airlines-bailout-protected-by-taxes-and-fare-floor-527571], Accessed 5 May 2021. 
ceived state aid in amount of 7 billion euro. These include an improvement in fleet efficiency (which does not necessarily lead to lower overall emissions if the increased efficiency is cancelled out by increased traffic), use of a minimum $2 \%$ of alternative fuels by 2025 (not necessarily low-carbon fuels) and the reduction of domestic greenhouse gas emissions by $50 \%$, but sufficient criteria for monitoring this obligation are not set. ${ }^{83}$ Other European airlines were given bailouts with no conditions of a similar nature, which shows that member states strongly favoured their economic recovery and did not make this opportunity to speed up the sector's green transition. Given the slow-moving pace of the CORSIA international framework for greenhouse gas emission reductions under the ICAO, it is becoming more and more likely that the aviation sector will face a challenging path out of a fossil fuel lock-in.

From all of the abovementioned, it can be concluded that some opportunities for preventing a fossil-fuel lock in have so far been missed at the member state level. However, the biggest part of the post-pandemic recovery public spending is yet to take place, within the scope of the Recovery and Resilience Facility. If fossil fuel lock-in is to be avoided, environmental criteria contained therein are not to be compromised and their stringent application of should be given priority.

\section{CONCLUSION}

In December 2019, the European Green Deal marked an important shift in the European Union's political agenda and expressly identified tackling climate change and environmental protection as the biggest task that the Union is faced with. ${ }^{84}$ The COVID-19 pandemic which followed shortly after the first steps for the implementation of the Green Deal were being taken has tested the dedication of Union's citizens, member states and institutions to pursue environmental aims, along with handling other pressing health and economic challenges. Despite some initial concerns about the additional financial pressure that the implementation of the Green Deal might put on their economies which were severely hit by the pandemic, the European Union never seriously considered to abandon the Green Deal. Some legislative delays in the implementation did take place, but the European Commission made sure to prioritise the essential parts of the Green Deal's agenda.

83 Transport \& Environment, Air France's bailout 'climate conditions' explained, [https://www.transportenvironment.org/publications/air-frances-bailout-climate-conditions-explained], Accessed 5 May 2021.

84 European Commission, Communication from The Commission to the European Parliament, the European Council, the Council, the European Economic and Social Committee and the Committee of the Regions - The European Green Deal, COM(2019) 640 final, page 2. 
In order to facilitate the post-pandemic recovery of member states' economies, the European Union adopted a temporary recovery instrument of 750 billion euro, the Next Generation EU, and made amendments to its long-term budget, the Multiannual Financial Framework. 30\% of the overall spending of both the Multiannual Financial Framework and the Next Generation EU are to be dedicated to climate action and all spending under these instruments is to be consistent with the aims of the Paris Agreement and the 'do no significant harm principle'. The main part of the Next Generation EU recovery package is the 672.5 billion euro Recovery and Resilience Facility. In order to benefit from its funding, member states have to draft national energy plans which must dedicate $37 \%$ of the spending to the green transition and comply with the 'do no significant harm' principle. Given the unprecedented volume of investments which will take place in the upcoming years and their potential for driving the green transition, strict application of these criteria and ensuring high environmental integrity of the sustainable investment taxonomy which will guide those investments will be of crucial importance. Any other option would lead to a sever risk of a fossil-fuel lock in and endanger the achievement of the goals of the Green Deal and the Paris Agreement.

The COVID-19 pandemic has demonstrated that decisive and large-scale state action is possible in case of an imminent threat and when public support is present. This can be illustrated by the size of the funding which the European Union mobilised in response to the pandemic - the recovery plan itself, Next Generation EU, amounts to 750 billion euro. Similarly, in response to the pandemic, the European Central Bank announced a 870 billion euro bond buying programme in $2020 .{ }^{85}$ In comparison, the pre-pandemic plans for the financing the Green Deal amounted to 1 trillion euro of both public and private investments over one decade. ${ }^{86}$ Given the size of the additional financial resources which are potentially available for green investments, there is an opportunity for an overall positive impact of the pandemic on the green transition.

85 Lagarde, C., Our response to the coronavirus emergency, The ECB blog, 19 March 2020, [https://www. ecb.europa.eu/press/blog/date/2020/html/ecb.blog200319 11f421e25e.en.html], Accessed 5 May 2021. The European Central Bank has not used its purchase programme to promote green investments, but has in the meantime been exploring options of such course of action. Taylor, K., European Central Bank sets up climate team, considers green bonds, Euractiv, 29 January 2021, [https://www. euractiv.com/section/energy-environment/news/european-central-bank-sets-up-climate-team-considers-green-bonds/], Accessed 5 May 2021.

86 European Commission, Financing the green transition: The European Green Deal Investment Plan and Just Transition Mechanism, Press Release, 14 January 2020, [https://ec.europa.eu/commission/presscorner/detail/en/ip_20_17], Accessed 5 May 2021. 


\section{REFERENCES}

\section{BOOKS AND ARTICLES}

1. Čavoški, A., An ambitious and climate-focused Commission agenda for post COVID-19 EU, Environmental Politics, Vol. 29, No. 6, 2020, pp. 1112-1117, DOI: 10.1080/09644016.2020.1784010

2. Dupont, C.; Oberthür, S.; von Homeyer, I., The Covid-19 crisis: a critical juncture for EU climate policy development?, Journal of European Integration, Vol. 42, No. 8, 2020, pp. 10951110, DOI: $10.1080 / 07036337.2020 .1853117$

3. Gemenne, F.; Depoux, A., What our response to the COVID-19 pandemic tells us of our capacity to respond to climate change, Environmental Research Letters, Vol 15, 2020, 101002, https://doi.org/10.1088/1748-9326/abb851

4. Hepburn, C., et al, Will COVID-19 fiscal recovery packages accelerate or retard progress on climate change?, Smith School Working Paper 20-02, [https://www.smithschool.ox.ac.uk/ publications/wpapers/workingpaper20-02.pdf], Accessed 5 May 2021

5. Kulovesi K.; Oberthür, S., Assessing the EU's 2030 Climate and Energy Policy Framework: Incremental change toward radical transformation? Review of European, Comparative and International Environmental Law (RECIEL) Vol. 29, No. 2, pp. 151-166, DOI: 10.1111/ reel. 12358

6. Ossewaarde, M.; Ossewaarde-Lowtoo, R., The EU's Green Deal: A Third Alternative to Green Growth and Degrowth?, Sustainability, Vol. 12, No. 23, 2021, 9825; https://doi. org/10.3390/su12239825

7. Scott, J., Reducing the EU's Global Environmental Footprint, German Law Journal, Vol. 21, 2020, pp. 10-16

8. Torney, D., European Climate Leadership in Question - Policies toward China and India, The MIT Press, 2015

9. Wurzel, R. K. W.; Liefferink, D.; Connelly, J., Introduction European Union climate leadership, in Wurzel, R. K. W.; Connelly, J.; Liefferink, D., (eds.), The European Union in International Change Politics - Still taking a lead?, Routledge, 2018

\section{EU LAW}

1. European Commission, Communication from The Commission to the European Parliament, the European Council, the Council, the European Economic and Social Committee and the Committee of the Regions - The European Green Deal, COM(2019) 640 final

2. European Commission, Communication from The Commission to the European Parliament, the European Council, the Council, the European Economic and Social Committee and the Committee of the Regions - The European Green Deal, COM(2019) 640 final, Annex to the Communication on the European Green Deal: Roadmap - Key Actions

3. European Commission, Communication from The Commission to the European Parliament, the European Council, the Council, the European Economic and Social Committee and the Committee of the Regions - Powering a climate-neutral economy: An EU Strategy for Energy System Integration, COM/2020/299 final. 
4. European Commission's Guidance to Member States - Recovery and Resilience Plans, SWD(2021) 12 final

5. European Commission Notice on Technical guidance on the application of 'do no significant harm' under the Recovery and Resilience Facility Regulation 2021/C 58/01, C/2021/1054, [2021] OJ C58/1

6. European Commission, Proposal for a Regulation of the European Parliament and of the Council establishing the framework for achieving climate neutrality and amending Regulation (EU) 2018/1999 (European Climate Law), COM/2020/80 final

7. Communication from the Commission to the European Parliament, the Council, the European Economic and Social Committee and the Committee of the Regions - A New Circular Economy Action Plan for a Cleaner and More Competitive Europe, COM/2020/98 final

8. Communication from the Commission to the European Parliament, the Council, the European Economic and Social Committee and the Committee of the Regions - A New Industrial Strategy for Europe, COM/2020/102 final

9. Communication from the Commission to the European Parliament, the Council, the European Economic and Social Committee and the Committee of the Regions - EU Biodiversity Strategy for 2030 Bringing nature back into our lives, COM/2020/380 final

10. Communication from the Commission to the European Parliament, the Council, the European Economic and Social Committee and the Committee of the Regions -A Farm to Fork Strategy for a fair, healthy and environmentally-friendly food system, COM/2020/381 final

11. Communication from the Commission to the European Parliament, the Council, the European Economic and Social Committee and the Committee of the Regions - Europe's moment: Repair and Prepare for the Next Generation, COM/2020/456 final

12. Communication from the Commission to the European Parliament, the Council, the European Economic and Social Committee and the Committee of the Regions - Stepping up Europe's 2030 climate ambition - Investing in a climate-neutral future for the benefit of our people, $\operatorname{COM}(2020) 562$ final

13. Council Regulation (EU, Euratom) 2020/2093 of 17 December 2020 laying down the multiannual financial framework for the years 2021 to 2027, [2020] OJ L 433I/11, Annex I.

14. European Parliament Resolution of 28 November 2019 on the climate and environment emergency (2019/2930(RSP)) [https://www.europarl.europa.eu/doceo/document/TA-92019-0078_EN.html], Accessed 5 May 2021

15. European Parliament Resolution of 17 April 2020 on EU coordinated action to combat the COVID-19 pandemic and its consequences (2020/2616(RSP), [https://www.europarl. europa.eu/doceo/document/TA-9-2020-0054_EN.html], Accessed 5 May 2021

16. Proposal for a Regulation of the European Parliament and of the Council establishing the Transition Fund, Just COM/2020/22 final

17. Regulation (EU) 2020/852 of the European Parliament and of the Council of 18 June 2020 on the establishment of a framework to facilitate sustainable investment, and amending Regulation (EU) 2019/2088, PE/20/2020/INIT

18. [2020] OJ L 198/13 
19. Regulation (EU) 2021/241 of the European Parliament and of the Council of 12 February 2021 establishing the Recovery and Resilience Facility, [2021] OJ L57/17

20. Special meeting of the European Council (17, 18, 19, 20 and 21 July 2020) - Conclusions, EUCO 10/20, [https://www.consilium.europa.eu/media/45109/210720-euco-finalconclusions-en.pdf], Accessed 5 May 2021

\section{WEBSITE REFERENCES}

1. Abnett, K., EU countries approve the green transition fund, look to challenges ahead, Reuters, 3 March 2021, [https://www.reuters.com/article/us-climate-change-eu-justtransitionidUSKCN2AV2D0], Accessed 5 May 2021

2. CAPA, Austrian Airlines bailout protected by taxes and fare floor, [https://centreforaviation. com/analysis/reports/austrian-airlines-bailout-protected-by-taxes-and-fare-floor-527571], Accessed 5 May 2021

3. Climate Home News, European Green Deal must be central to a resilient recovery after Covid-19, 9 April 2020, [https:/www.climatechangenews.com/2020/04/09/european-greendeal-must-central-resilient-recovery-covid-19/], Accessed 5 May 2021

4. Colli, F., The end of 'business as usual?' COVID-19 and the European Green Deal, Egmont - European Policy Briefs, No 60, May 2020, [https://www.egmontinstitute.be/content/uploads/2020/05/EPB60.pdf?type=pdf], Accessed 5 May 2021

5. Darvas, Z.; Tagliapietra, S., Setting Europés economic recovery in motion: a first look at national plans, Bruegel Blog, 29 April 2021, [https://www.bruegel.org/2021/04/setting-europes-economic-recovery-in-motion-a-first-look-at-national-plans/], Accessed 15 May 2021

6. Euractiv, Czech PM urges EU to ditch Green Deal amid virus, 17 March 2020, [https://www. euractiv.com/section/energy-environment/news/czech-pm-urges-eu-to-ditch-green-dealamid-virus/], Accessed 5 May 2021

7. Euractiv, Poland says virus fallout makes it 'even more difficult' to hit EU climate goal, 27 March 2020, [https://www.euractiv.com/section/energy-environment/news/poland-says-virus-fallout-makes-it-even-more-difficult-to-hit-eu-climate-goal/], Accessed 5 May 2021

8. European Commission, A European Green Deal, [https://ec.europa.eu/info/strategy/priorities-2019-2024/european-green-deal_en\#documents], Accessed 5 May 2021

9. European Commission, European Climate Law, [https://ec.europa.eu/clima/policies/euclimate-action/law_en], Accessed 5 May 2021

10. European Commission, Financing the green transition: The European Green Deal Investment Plan and Just Transition Mechanism, Press Release, 14 January 2020, [https://ec.europa.eu/ commission/presscorner/detail/en/ip_20_17], Accessed 5 May 2021

11. European Commission, Recovery Plan for Europe, [https://ec.europa.eu/info/strategy/recovery-plan-europe_en], Accessed 5 May 2021

12. European Commission, Recovery and Resilience Facility: Croatia and Lithuania submit official recovery and resilience plans, [https://ec.europa.eu/commission/presscorner/detail/en/ IP_21_2501], Accessed 15 May 2021

13. European Commission, Speech by President von der Leyen at the European Parliament Plenary on the EU coordinated action to combat the coronavirus pandemic and its con- 
sequences, 16 April 2020, [https://ec.europa.eu/commission/presscorner/detail/en/ SPEECH_20_675], Accessed 5 May 2021

14. European Commission, The Just Transition Mechanism: making sure no one is left behind, [https://ec.europa.eu/info/strategy/priorities-2019-2024/european-green-deal/actions-being-taken-eu/just-transition-mechanism_en], Accessed 5 May 2021

15. European Commission, Questions and Answers: Taxonomy Climate Delegated Act and Amendments to Delegated Acts on fiduciary duties, investment and insurance advice, [https://ec.europa. eu/commission/presscorner/detail/en/qanda_21_1805], Accessed 5 May 2021

16. Elkerbout, M., et al., The European Green Deal after Corona: Implications for EU climate policy, CEPS Policy Insights, No 2020-06 / March 2020, [https://www.ceps.eu/ceps-publications/the-european-green-deal-after-corona/], Accessed 5 May 2021

17. European Council, A new strategic Agenda 2019-2024, p. 5., https://www.consilium.europa.eu/media/39914/a-new-strategic-agenda-2019-2024.pdf], Accessed 5 May 2021

18. European Council, Council of the European Union, Timeline - Council actions on COVID-19, [https://www.consilium.europa.eu/en/policies/coronavirus/timeline/], Accessed 5 May 2021

19. European Parliament, 2019 European election results, [https://www.europarl.europa.eu/election-results-2019/en/tools/comparative-tool/], Accessed 5 May 2021

20. European Parliament, President Biden's climate summit [https://www.europarl.europa.eu/ RegData/etudes/ATAG/2021/690583/EPRS_ATA(2021)690583_EN.pdf], Accessed 5 May 2021

21. Fridays For Future, [https://fridaysforfuture.org/], Accessed 5 May 2021

22. Gornall, J., Climate change will still be a threat after COVID-19 is gone, Euractiv, 17 March 2020, [https://www.euractiv.com/section/climate-environment/opinion/climate-changewill-still-be-a-threat-after-covid-19-is-gone/], Accessed 5 May 2021

23. Greenpeace, European Airline Bailout Tracker, [https://www.greenpeace.org/eu-unit/issues/ climate-energy/2725/airline-bailout-tracker/], Accessed 5 May 2021

24. Green Recovery Tracker, Country reports, [https://www.greenrecoverytracker.org/countryreports-overview], Accessed 15 May 2021

25. International Energy Agency, Net Zero by 2050 - A Roadmap for the Global Energy Sector, [https://iea.blob.core.windows.net/assets/4482cac7-edd6-4c03-b6a2-8e79792d16d9/ NetZeroby2050-ARoadmapfortheGlobalEnergySector.pdf], Accessed 18 May 2021

26. Joint statement of the Members of the European Council, 26 March 2020, [https://www.consilium.europa.eu//media/43076/26-vc-euco-statement-en.pdf?utm_source=POLITICO. EU\&utm_campaign=11f700a891-EMAIL_CAMPAIGN_2020_03_26_10_12\&utm_ medium=email\&utm_term=0_10959edeb5-11f700a891-189693589], Accessed 5 May 2021

27. Kucharczyk, M., West Poland subregion aims to be first in the country to hit net zero, 21 January 2021, Euractiv, [https://www.euractiv.com/section/energy/news/west-poland-subregionaims-to-be-first-in-the-country-to-hit-net-zero/], Accessed 5 May 2021 
28. Lagarde, C., Our response to the coronavirus emergency, The ECB blog, 19 March 2020, [https://www.ecb.europa.eu/press/blog/date/2020/html/ecb.blog200319 11f421e25e. en.html], Accessed 5 May 2021

29. Legislative Train Schedule, New Boost for Jobs, Growth and Investment [https://www.europarl. europa.eu/legislative-train/theme-new-boost-for-jobs-growth-and-investment/file-mff2021-2027-mff], Accessed 5 May 2021

30. Oroschakoff, K., Coronavirus crisis cash threatens EU green plans, Politico, March 19, 2020, [https://www.politico.eu/article/coronavirus-crisis-cash-threatens-eugreen - plans $/$ ?utm_source $=$ POLITICO.EU\&utm_campaign=0199d $91 \mathrm{bba}-E M A I L$ CAMPAIGN_2020_05_22_01_28\&utm_medium=email\&utm_term=0_10959edeb50199d91bba-189693589], Accessed 5 May 2021

31. Piccard, B.; Timmermans, F., Which world do we want after COVID-19?, Euractiv, 16 April 2020, [https://www.euractiv.com/section/energy-environment/opinion/which-world-dowe-want-after-covid-19/], Accessed 5 May 2021

32. Politico, [https://www.politico.eu/wp-content/uploads/2020/03/vdL-Sassoli-Michel-letter-26. 03.2020-signatures-as-of-29.03.2020.pdf?utm_source=POLITICO.EU\&utm_ campaign=4eb3480635-EMAIL_CAMPAIGN_2020_03_30_04_568utm_ medium=email\&utm_term=0_10959edeb5-4eb3480635-189693589], Accessed 5 May 2021

33. Posaner, J., German coalition agrees $€ 130 B$ economic rescue package, 4 June 2020, Politico, [https://www.politico.eu/article/german-coalition-agrees-e130b-economic-rescue-package/], Accessed 5 May 2021

34. Potočnik, J., The European Green Deal and a post Covid-19 prosperity, [https://medium.com/ circulatenews/the-european-green-deal-and-a-post-covid-19-prosperity-e95608f7606f], Accessed 5 May 2021

35. Simon, F., 2020: A test year for Europe's much-vaunted Green Deal, 2 January 2020, [https:// www.euractiv.com/section/energy-environment/news/2020-a-test-year-for-europes-muchvaunted-green-deal/], Accessed 5 May 2021

36. Simon, F., EU leaders back 'green transition' in pandemic recovery plan, Euractiv, 27 March 2020, [https://www.euractiv.com/section/energy-environment/news/eu-leaders-backgreen-transition-in-pandemic-recovery-plan/], Accessed 5 May 2021

37. Simon, F., Leaked: Full list of delayed European Green Deal initiatives, Euractiv, 16 April 2020, [https://www.euractiv.com/section/energy-environment/news/leaked-full-list-of-delayed-european-green-deal-initiatives/], Accessed 5 May 2021

38. Simon, F., Gas denied 'transition' fuel status in draft EU green finance rules, 11 November 2020, Euractiv, [https:/www.euractiv.com/section/energy-environment/news/gas-deniedtransition-fuel-status-in-eu-green-finance-rules/], Accessed 5 May 2021

39. Simon, F., Brussels postponed green finance rules after 10 EU states wielded veto, 29 January 2021, Euractiv, [https://www.euractiv.com/section/energy-environment/news/brusselspostponed-green-finance-rules-after-10-eu-states-wielded-veto/], Accessed 5 May 2021

40. Special Eurbarometer Report, 490 Climate Change, April 209, p. 9-10., [https://ec.europa. eu/clima/sites/clima/files/support/docs/report_2019_en.pdf], Accessed 5 May 2021 
41. Taylor, K., European Central Bank sets up climate team, considers green bonds, Euractiv, 29 January 2021, [https://www.euractiv.com/section/energy-environment/news/europeancentral-bank-sets-up-climate-team-considers-green-bonds/], Accessed 5 May 2021

42. Taylor, K., Historic step' as European Parliament approves green recovery fund, Euractiv, 10 February 2021, [https://www.euractiv.com/section/energy-environment/news/historic-step-aseuropean-parliament-approves-green-recovery-fund/], Accessed 5 May 2021

43. Taylor, K., Czechs lead the charge against EU's 'do no harm' green criteria, 26 March 2021, Euractiv, [https://www.euractiv.com/section/climate-environment/news/czechs-lead-thecharge-against-eus-do-no-harm-green-criteria/], Accessed 5 May 2021

44. Transport \& Environment, Air France's bailout 'climate conditions' explained, [https://www. transportenvironment.org/publications/air-frances-bailout-climate-conditions-explained], Accessed 5 May 2021

45. Transport \& Environment, Austrian Airlines' bailout 'climate conditions' explained, [https:// www.transportenvironment.org/publications/austrian-airlines-bailout-climate-conditionsexplained], Accessed 5 May 2021

46. Transport \& Environment, Bailout Tracker, [https://www.transportenvironment.org/whatwe-do/flying-and-climate-change/bailout-tracker], Accessed 5 May 2021

47. UN, COP 26 postponed [https://unfccc.int/news/cop26-postponed], Accessed 5 May 2021 